\title{
TRADITIONAL VS. UV-CURED COATINGS - AN INQUIRY-BASED EXPERIMENT FOR INTRODUCING GREEN CHEMISTRY
}

\author{
Kinga Orwat ${ }^{1}$, Paweł Bernard ${ }^{1, *}$, Szymon Wróblewski ${ }^{2}$, James D. Mendez ${ }^{3}$ \\ ${ }^{1}$ Jagiellonian University in Kraków, Department of Chemical Education, 2 Gronostajowa Str., \\ 30-387 Kraków, Poland \\ ${ }^{2}$ PPG Polifarb Cieszyn, 16 Chemików Str., 43-400 Cieszyn, Poland \\ ${ }^{3}$ Indiana University - Purdue University Columbus, 4601 Central Ave., Columbus IN 46131, USA \\ pawel.bernard@uj.edu.pl
}

The aim of this article is to present a hands-on laboratory experiment, which enables students to become acquainted with the idea and some principles of green chemistry in the context of the manufacture and use of lacquers. Environmental concerns, particularly the regulations concerning Volatile Organic Compounds have resulted in a dramatic change in the coating markets and traditional solvent-based (SB) technologies are being replaced by new, environmentally friendly processes based on ultraviolet (UV) or electron beam (EB) curing. In this exercise, the technological processes of SB and UV lacquers production and application were simplified and adapted for a school laboratory. The obtained lacquers are fully functional products with repeatable, easily measurable properties, which depend on the composition directly. The proposed method in this exercise is based on guided inquiry, however, it may be realized in a more or less open form, depending on the teacher's goals, needs, and preferences.

Keywords: high school/introductory chemistry; laboratory instruction; inquiry-based learning; green chemistry; paints/lacquers

\section{ТРАДИЦИОНАЛНО НАСПРОТИ СО UV-ЗРАЦИ ПОТПОМОГНАТО СТВРДНУВАЊЕ НА БОИ И ЛАКОВИ - ЕКСПЕРИМЕНТ БАЗИРАН НА ИСТРАЖУВАЫЕ КАКО ВОВЕД ВО ЗЕЛЕНА ХЕМИЈА}

Целта на овој труд е да се презентира лабораториски експеримент кој им овозможува на учениците да се запознаат со идејата и некои принципи на зелената хемија во контекст на производството и употребата на лакови. Загриженоста за животната средина, особено прописите што се однесуваат на испарливите органски соединенија, доведоа до драматична промена на пазарот на бои и лакови и традиционалните технологии базирани на растворувачи (SB) ce заменуваат со нови, еколошки прифатливи процеси базирани на стврднување со ултравиолетови (UV) или со електронски зраци (ЕВ). Во оваа вежба технологиите базирани на разредувачи и производството на лакови потпомогнато со UV зраци се поедноставени и приспособени за училишна лабораторија. Добиените лакови се целосно функционални производи со повторливи и мерливи својства, што директно зависи од составот. Предложениот метод е вежба базирана на насочено испитување, но може да се реализира и во поотворена форма во зависност од целите на наставникот, потребите и желбите.

Клучни зборови: средношколска/факултетска хемија; лабораториска вежба; истражувачки базирано учење; зелена хемија; бои и лакови 


\section{INTRODUCTION}

Green chemistry $[1,2]$ is a relatively new area of chemistry, which has arisen because of a need to develop environmentally friendly and sustainable methods of synthesis utilizing nontoxic substances and solvents which are benign to the environment [3]. The Pollution Prevention Act [4] from 1990 contributed to the creation of the 12 Principles of Green Chemistry [1, 5]. Anastas and Kirchhoff [6] indicate that the philosophy, definition, and principles of green chemistry may be introduced to students at every level of education. The challenge is to incorporate the green chemistry into the curriculum and link it with the subject's content and connect it to the everyday life [7]. Lacquer manufacturing and application is one of the industrial branches which can be used to illustrate the process of greening up technological processes. Environmental concerns, particularly regulations concerning VOCs (Volatile Organic Compounds) have resulted recently in a dramatic change in coating markets. Traditional solventbased (SB) techniques are being replaced by new environmentally friendly Radiation Curable (ultraviolet - UV, or electron beam - EB), Powder and Water Based coatings [8].

Traditional lacquers consist of two main parts: a volatile and a non-volatile one [9]. The basic component of the non-volatile part of the lacquer is constituted by macromolecular compounds [10], including lacquers based on a natural polymer - cellulose which has been esterified using nitric acid [11]. Nitrocellulose (NC) lacquers have a great historical significance [10], and their production still occupies a significant part of the lacquers' market. For preparation of the lacquer which is literally a solution of cellulose nitrate, organic solvents are used which typically comprise $65-80 \%$ by mass of the lacquer. The solvent should be practically colorless, in order to avoid any disturbance of the lacquers color, and should contain no acids or substances which may corrode metals or damage wooden surfaces [10, 12]. Additionally, the solvent type and content is adjusted to the expected drying rate [11] and odor (toxicity of the vapors). Typical solvents used in the manufacturing of nitrocellulose lacquers include i.e.: ethyl ethanoate, pentanol, xylene, cyclohexanol. Usually, a pure nitrocellulose layer does not form the desired protective or decorative coating, for that reason additives are used: resins, plasticizers and colorants [13-15]. Unfortunately, traditional lacquer technology has sighnificant limitations. The most important one is a high
VOCs level - up to $800 \mathrm{~g}$ of solvent emitted to the atmosphere from $1 \mathrm{~kg}$ of applied product, in addition to solvent evaporation during the manufacturing process and transportation. Finally, from the EHS (Environment, Health and Safety) point of view, there is the extreme flammability of $\mathrm{NC}$ lacquers and risk of an explosion related to nitrocellulose flakes being handled during production.

Development and growth of radiationcurable technology in the coatings market is an excellent example of the theory of green chemistry becoming industrial reality [16] and can be evaluated at several levels. The first and most obvious aspect is the fact that, unlike the traditional coatings, radiation-curable products do not contain any solvents [17], therefore there is no pollution emission to the atmosphere. Besides being VOCs-free, which means no solvent emission, there are other green aspects of the UV technology, such as a low energy consumption and Raw Materials (RM) which can be based on natural, oil-based, or biorenewable sources $[18,19]$. A high drying rate is an additional benefit of UV curing. Where conventional drying of coatings may last for several minutes up to several hours at a high temperature, UV coatings can be cured within seconds at room temperature [20]. Apart from all the mentioned environmental benefits, the UV- or EB-cured technology has much more to offer, both on the cost side (fast drying - increased speeds, reduced handling time), and in coating performance (high chemical and abrasion resistance, high gloss). Comparison of UV-cured and classical lacquer curing processes is schematically presented in Figure 1.

The term "UV radiation curing" is used to describe the conversion of a liquid into a solid or the change in the physical properties of the polymer, by means of UV radiation [16, 21, 22]. The simplest type of a UV-cured mixture contains the three types of ingredients: prepolymers (oligomers), a reactive diluent (monomers) and a photoinitiator (PI). The prepolymer is a relatively high-molecular-weight material which contains several functional groups responsible for the polymerization process. Nowadays, the most common technology is based on acrylate chemistry and a radical polymerization mechanism during the coating film formation. There are several types of prepolymers in use with different backbone structures, such as epoxy acrylates, urethane acrylates, polyester acrylates, polyether acrylates and acrylated oils [23]. Usually, the prepolymers have a high viscosity and therefore are difficult to apply onto materials. For this reason, reactive diluents 
are added to the mixture. These compounds belong to the group of mono/multifunctional acrylate esters. The diluents reduce the viscosity of the formulation and can be used to control the reactivity of the system and the crosslink density. The photoinitiator (PI) is a compound intentionally added to the formulation to absorb light and generate radicals. Benzoin/benzoin ethers and benzophenone are used as photoinitiators. As a UV-light source traditional mercury lamps can be used but nowa- days those are being replaced by LED (Light Emitting Diodes) technology with an increased flexibility (3D application), low temperature (suitable for heat sensitive substances) and reduced energy consumption [16].

The goal of this article is to present a simple, school laboratory exercise which can serve as an introduction to green chemistry and the principles in the context of lacquer manufacturing and application technology.

\section{Classical lacquer}

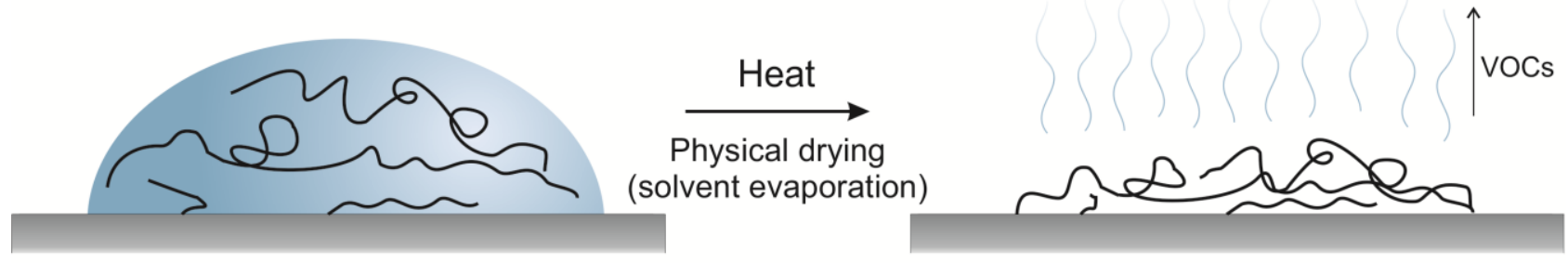

\section{UV lacquer}

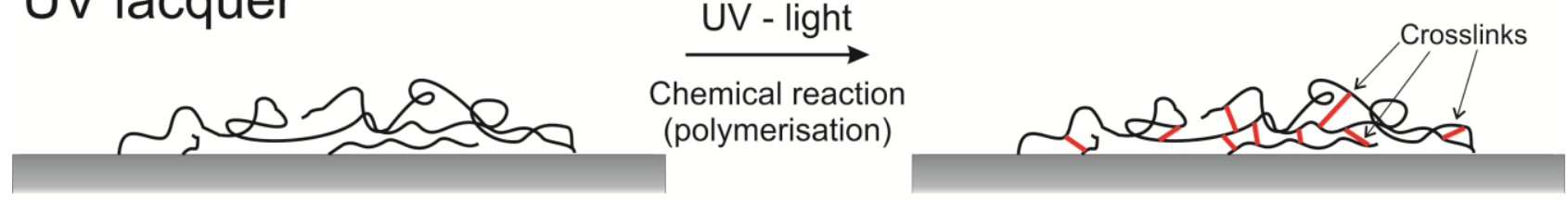

Fig. 1. Comparison of UV-cured and classical lacquer curing processes

\section{EXPERIMENTAL}

\subsection{Preparation of cellulose lacquers}

Preparation of a cellulose lacquer requires cellulose nitrate, a relatively dangerous propellant explosive [24]. Another option is to use cellulose acetate or table tennis balls that are composed of a mixture containing these compounds [25]. When pure nitrocellulose is used, the lacquer is colorless, however, it forms a coating with a slightly milky appearance when dried. In the case of table tennis balls, the color of the lacquer and the coating is more intense and corresponds to the color of the balls. In the school laboratory, the nitrocellulose or table tennis balls can be dissolved in acetone (mass ratio $1: 9$ ). It is advised to use this diluent because of its high evaporation rate, resulting in a high drying rate of the prepared lacquer. The components should be mixed until the solid is completely dissolved ( 20 minutes) avoiding vigorous mixing in order to prevent foaming of the product. The obtained lacquer should be stored in a tightly sealed container (see a detailed procedure for students in the Supporting information).

\subsection{Preparation of $U V$-lacquers}

In order to prepare a simple UV-cured lacquer, three following components should be mixed: a prepolymer, a reactive diluent, and a photoinitiator. Unfortunately, not every mixture of the available precursors yields an active lacquer when exposed to oxygen in the atmosphere. Molecular oxygen easily reacts with free radicals and creates peroxy radicals that significantly lower the curing rate resulting in a tacky, uncured surface. A composition of a UV lacquer that can be easily obtained in school laboratory under the air atmosphere was found empirically, and presented in the Table 1.

Suggested prepolymer (Laromer UA 9033) is a solvent-free difunctional aliphatic urethanemodified acrylic resin. Films from this prepolymer exhibit low yellowing and high elasticity. It is used in the manufacture of radiation-curable printing inks and coatings for wood, paper and plastics. The exact structure of the oligomer is protected by patent, general structure of aliphatic urethane acrylates prepolymers is showed in Figure 2 [16]. 
Table 1

The composition of UV-cured lacquer

\begin{tabular}{l|c|l|l}
\hline \hline Ingredient & Percent by mass & Substance & Industrial product \\
\hline Prepolymer & $45 \%$ & urethane acrylates & Laromer 9033 \\
Reactive diluent & $50 \%$ & $\begin{array}{l}\text { trimethylolpropane triacrylate } \\
\text { a mix of 1-hydroxycyclohexyl phenyl ketone } \\
\text { and benzophenone, ratio 50:50 }\end{array}$ & Laromer TMPTA \\
Photoinitiator & $5 \%$ & Irgacure 500 \\
\hline \hline
\end{tabular}

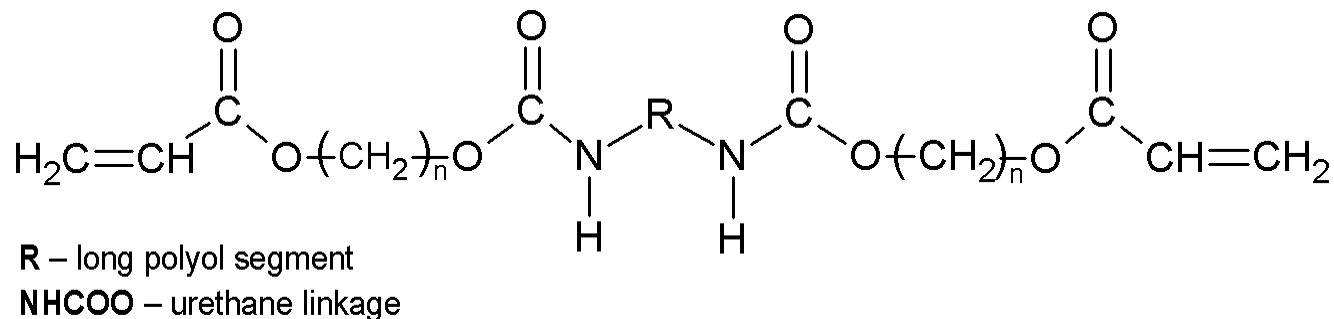

Fig. 2. A general structure of the polyurethane-modified acrylic resin [16]

Laromer UA 9033 can be used as a sole binder. Despite the fact that it contains about $30 \%$ of dilutant - trimethylolpropaneformal monoacrylate (Fig. 3) it has high viscosity (15-25 Pa.s), and for this application, viscosity adjustment is necessary.

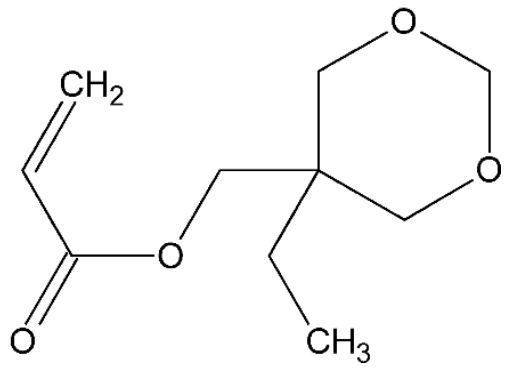

Fig. 3. A structure of trimethylolpropaneformal monoacrylate

Trimethylolpropane triacrylate (TMPTA) was used as a reactive dilatant that is a liquid with low viscosity and low volatility. It is classified as trifunctional monomer, because it contains three polymerizable acrylic groups per molecule (Fig. 4). This functionality results in an improvement in reactivity and the creation of high density polymer network. These properties with high curing response make TMPTA a key component in the formulation of coating. It is used to control cure speed, viscosity of the formulation, and influence adhesion, weatherability, hardness, scratch and chemical resistance of the cured product. It is widely used in production of plastics, adhesives, acrylic glue, anaerobic sealants, inks, paper and wood coatings, wire and cable extrusion, polymer- impregnated concrete, and polymer/concrete structural composites [26].

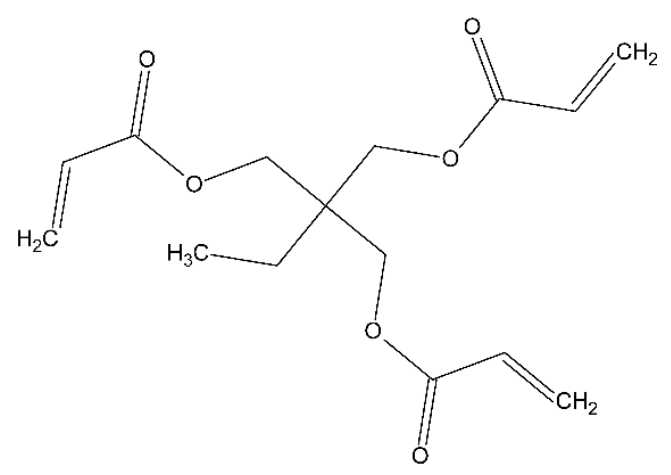

Fig. 4. Trimethylolpropane triacrylate (TMPTA) structure

To start radical polymerization reaction the curing process - a photoinitiator is necessary. Irgacure 500, being a $1: 1$ mixture by weight of two compounds: 1-hydroxycyclohexyl phenyl ketone and benzophenone (Fig. 5) was used for this purpose. It is commonly used to initiate the polymerization of chemically unsaturated prepolymers (e.g. acrylates) in combination with mono or multifunctional monomers. It is a yellowish liquid that is used in several commercial applications as a UV-curable clear coating for paper, metal and plastic. It also has a low viscosity that can reduce the viscosity of the total formulation.

In general, photoinitiators can be divided into two groups: type I photoinitiators that undergo a unimolecular bond cleavage upon irradiation to yield free radicals and type II photoinitiators that 
undergo a bimolecular reaction where the excited state of the photoinitiator interacts with a second molecule (a coinitiator/synergist) to generate free radicals. The suggested product (Irgacure 500) is a mixture of type I and II photoinitiators, 1-hydroxycyclohexyl phenyl ketone is classified as type I (Fig. 5a), whereas benzopheneone type II (Fig. 5b). This mixture is characterized by two absorption peaks: 250 and $332 \mathrm{~nm}$ (spectrum in methanol [27]), and fair resistance to oxygen in the atmosphere.

a)<smiles>O=[C]c1ccccc1</smiles>

b)<smiles>O=C(c1ccccc1)c1ccc(-c2cccc([C+]([O-])c3ccccc3)c2)cc1</smiles>

Fig. 5. Structures of a) 1-hydroxycyclohexyl phenyl ketone and $\mathbf{b})$ benzophenone and its radicals

A typical free radical polymerization starts with initiation (generation of free radicals), follows with multiple propagation steps and finally is terminated in process where radicals are recombined to stable molecules [16]. Because of a large variety of species in the reacting mixture there is no point in considering subsequent propagation steps at school level. However all reacting monomers and oligomers have the same acrylate functional group, therefore the main idea of polymerization can be described relatively simple, as shown in Figure 6.
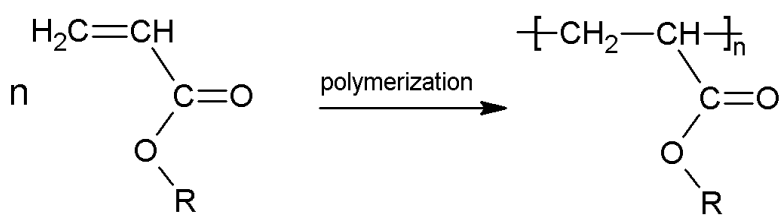

Fig. 6. A general scheme of acrylates polymerization process

In this experiment, the lacquer components should be introduced in the given ratios into a high vessel and mixed for approximately 20 minutes. Due to the high viscosity of the mixture, use of a mechanical stirrer is necessary. To avoid foaming of the lacquer, speed in the range of $250-350 \mathrm{rpm}$ is suggested (a detailed procedure is presented in the Supporting information). In order to obtain a white coating, $\mathrm{TiO}_{2}$ powder may be added to the mixture ( $\mathrm{ca} .5 \%$ by mass). The obtained lacquer should be stored in a closed airtight container made from a dark material to protect the composition from direct sunlight exposition.

\subsection{Application and film property testing}

The lacquers obtained can be applied by an ordinary paintbrush or using dedicated applicators (Leneta Wire-Cators [28]), the latter produces a more even film with a selected thickness that has important influence on both the SB film drying and UV curing. The students should carry out the first painting using sheets specially designed for this purpose - Leneta cards (charts for coatings tests [29]). Then, they can start painting other surfaces e.g.: glass, plastic, wood, cardboard. The surfaces painted with the solvent-based lacquer should be dried in a laboratory oven at $50^{\circ} \mathrm{C}$ for $c a .10$ minutes. The UV lacquers should be placed under UV light for approx. 2 minutes. A laboratory UV lamp may be used, or lamps used for home curing of nail lacquers (LED lamps, power > $20 \mathrm{~W}$ ).

The students may perform simple tests to determine coatings properties. The most common test is the "thumb-twist" test that let verify hardness and adhesion of a coating. Simple bending of a painted surface is used to check coating elasticity and brittleness. A few drops of diluted potassium permanganate applied on the lacquer layer tests double bonds conversion and, therefore, process competition. Finally, a few pencils of various hardness may be used to determine hardness of the lacquer surface $[16,30]$ (see exemplary test procedures presented in the Supporting information). The students should also determine the loss of the lacquer mass during curing (simple way to measure Solid Content - SC or VOCs).

\subsection{Chemicals}

- Irgacure 500 - 50\% 1-hydroxycyclohexyl phenyl ketone (CAS: 947-19-3) and 50\% benzophenone (CAS: 119-61-9), BASF.

- Laromer TMPTA (trimethylolpropane triacrylate) CAS: 15625-89-5, BASF.

- Laromer UA 9033 (a mixture of urethane acrylates), BASF.

- Acetone, CAS: 67-64-1, Sigma-Aldrich.

\subsection{Safety tips and hazards}

The synthesis and painting with both types of lacquers should be carried out in a fume hood. 
Precursors of the UV-cured lacquer are classified as irritating. Students should use standard personal protective measure: lab coats, googles and gloves, avoid breathing in vapors of reactants and obtained lacquers. During the curing process, students should avoid staring at UV light, and if high-power laboratory UV lamp is used, proper googles with filters must be worn. Acetone used for classical lacquer preparation and washing tools is toxic and flammable. Cellulose nitrate is an explosive compound, should be handled with special care (it is recommend to use table tennis balls instead). It is strictly forbidden to use the obtained lacquers for painting nails! All the wastes should be placed in an appropriate organic waste container.

\section{IMPLEMENTATION OF THE EXERCISE}

\subsection{Organization of the classes}

At the high school level, it is recommended to implement this exercise in the form of a guided inquiry [31]. In this method, the teacher provides the students with a problem to investigate, but the selection of the methods for resolving the problem is left to the students [32]. There are two general questions that can be delivered by teacher: Which lacquer (UV-cured or traditional) is better? and Which of the obtained lacquers is "green"?. The first question has an ambiguous and open character, the students have to agree on their understand- ing of the term better, as well as on the features which may be compared and the method for carrying out the comparison. To answer the second question, the students must analyze the composition, the properties and the processes of preparation and drying of the compared lacquers.

Students prepare traditional and UV-cured lacquers following the procedures enclosed in the Supporting Information. This is a pre-inquiry phase, and its goal is to acquaint students with the compositions and preparative procedures of the lacquers, as well as physical and chemical properties of the lacquers' components. Then, the students select their own surfaces to be painted with the obtained lacquers, select the parameters being compared and develop the testing methods. The teacher can structure the inquiry process using the materials enclosed in the Supporting information, in any configuration, depending on the selected goals and the skills being targeted. The exercise may be implemented during two laboratory sessions, the suggested timetable of these stages is shown in Table 2.

The green chemistry aspects of lacquers are discussed during second laboratory session. Students compare properties of lacquers and their precursors, analyze the drying/curing processes, and discusses which lacquer is green and why. If this is the students' first experience with green chemistry, they have to become acquainted with the definition and principles of green chemistry.

Table 2

The timetable of the exercise's realization

\begin{tabular}{|c|c|c|c|}
\hline & Realization stage & $\begin{array}{c}\text { Approximated } \\
\text { realization time }\end{array}$ & $\begin{array}{c}\text { Realization time } \\
\text { by blocks }\end{array}$ \\
\hline \multicolumn{2}{|r|}{ Pre-test } & $20 \min$ & $20 \min$ \\
\hline \multirow{4}{*}{$\begin{array}{l}\widetilde{\Xi} \\
\widetilde{0} \\
\tilde{\omega} \\
\tilde{\omega} \\
\tilde{\omega}\end{array}$} & Introductory discussion & $20 \mathrm{~min}$ & \multirow{4}{*}{$135 \mathrm{~min}$} \\
\hline & Preparation of the lacquers & $60 \mathrm{~min}$ & \\
\hline & Lacquering tests & $30 \mathrm{~min}$ & \\
\hline & Development of research procedures & $25 \mathrm{~min}$ & \\
\hline \multirow{5}{*}{ 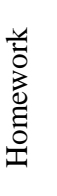 } & \multicolumn{3}{|l|}{ Students' tasks: } \\
\hline & \multicolumn{3}{|c|}{ Find the definition and principles of green chemistry. } \\
\hline & \multicolumn{3}{|c|}{ 2. Describe the idea of UV and traditional lacquer drying. } \\
\hline & \multirow{2}{*}{\multicolumn{3}{|c|}{$\begin{array}{l}\text { 3. List pros and cons for using UV and traditional lacquer (at least } 2 \text { for each). } \\
\text { 4. State one example of using green chemistry in the industry. }\end{array}$}} \\
\hline & & & \\
\hline \multirow{7}{*}{ 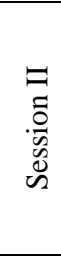 } & Discussion: What a green chemistry is? & $20 \mathrm{~min}$ & \\
\hline & Lacquering of the selected surfaces & $30 \mathrm{~min}$ & \multirow{5}{*}{$155 \mathrm{~min}$} \\
\hline & Studies of the coatings properties & $60 \mathrm{~min}$ & \\
\hline & Result analysis and conclusions & $15 \mathrm{~min}$ & \\
\hline & Discussion on Which the lacquer is better & $20 \mathrm{~min}$ & \\
\hline & Discussion on Which the lacquer is "green" & $10 \mathrm{~min}$ & \\
\hline & Post-test & $20 \mathrm{~min}$ & $20 \mathrm{~min}$ \\
\hline
\end{tabular}


This work can be shifted to self-study for homework, as is proposed in the timetable. The second session can start with a discussion about green chemistry definition and principles, the teacher moderates the discussion, check students' knowledge, identify and clear misconceptions. In the end of the second session students use knowledge about green chemistry in summary discussion and answering question: Which the lacquer is "green"?.

To determine the knowledge level of the students concerning the lacquers and green chemistry, before and after the classes, a test (enclosed in Supporting information) can be used. The part of the test concerning lacquers was developed specifically for this purpose, and the questions concerning green chemistry were adopted from those prepared by the ACS Green Chemistry Institute [33].

\subsection{Trial implementation}

The exercise was implemented with 6 groups of 12 students each in Polish secondary schools (K9 age: 16 and K11 age: 18) and a group of 20 students in an introductory chemistry lab course in a U.S. university. In Poland, students in classes K7-9 participate in an obligatory basic chemistry course (total: $130 \mathrm{~h}$ ), so students from the first half had basic chemistry knowledge and laboratory skills. In class K10 students obligatory attend $30 \mathrm{~h}$ high school chemistry course that can be voluntary extended in K11-12 (an additional $240 \mathrm{~h}$ ). Students from the other Polish groups were in their first year of extended chemistry course. The proposed exercise was the students' first formal meeting with the green chemistry issues, because those are not included in the Polish science curriculum at any stage of the education. Moreover the inquiry-based methods are not widely used in Polish schools [34, 35], therefore the students in all Polish groups have had no experience in autonomous investigations. For that reason, a highly structured guided inquiry was applied in all cases. The students used recipes and worksheets enclosed in Supporting information. In every case, the students worked in three-person groups and could choose the compositions of groups freely. Each of the groups completed a pre-test a week before and a post-test a week after the exercise.

The university trial was conducted near the end of a second semester introductory chemistry course after a brief introduction of organic chemistry. However, green chemistry was not part of the typical curriculum and this lab was the students' first introduction to the topic.

\subsection{Modifications and extensions}

Due to the advanced stage of the technologies used currently, particularly the production of UV-cured lacquers, the exercise may be modified easily, expanded in its scope and used at a higher educational level. For instance, while working with the students learning chemistry at the extended level and having experience in laboratory work, lacquers having a more complex composition may be prepared and the bounded inquiry approach may be used to investigate the effect of the mixture composition on the properties of the lacquer. For the UV-cured lacquers, it may be interesting to examine the impact of selected components of the lacquer on its viscosity, reactivity, flexibility, hardness, and gloss.

The viscosity range may be measured readily using flow cup viscometers. The product viscosity is an important parameter from the industrial point of view since to a large extent, it determines whether the product may be applied by a customer using their available equipment. The lacquer must be fully cured once applied in a defined film thickness and exposed to available UV sources for a defined time period. The selection of the prepolymers and monomers (mainly their functionality), the photoinitiator types and concentration, as well as the curing conditions (lamp power, oxygen or inert atmosphere) will contribute to the rate of conversion of the liquid coating into a solid cured film. There are strict and logical correlations between all those parameters and the RM selection, with the monomers having the biggest influence which can be evaluated during this student exercise.

Viscosity, flexibility and reactivity are related to the chemistry of the molecules, molecular weight and structure - especially the functionality or the number of acrylate groups per molecule. An increase in the monomer functionality causes an increased reactivity, an increased hardness (a lower flexibility), a better chemical resistance, but a higher viscosity and gloss in the final cured film.

One of the challenges to be faced by the UV coating formulators is the fact that, unlike the traditional SB technologies, the finishes have a low or even a semi-gloss finish. $100 \%$ solid composition and a low film shrinkage during the film formation result in a high gloss surface appearance which is not always acceptable. In order to adjust the surface gloss, the formulator has to adjust the formulation reactivity (the amount of the photoinitiator), the type of the binder and the monomer functionality, and often they have to incorporate an addition- 
al raw material to modify the surface morphology in order to obtain low gloss finishes. Popular matting additives which can be evaluated during the exercise include silica (high matting efficiency but strong influence on viscosity) and waxes.

The described exercise may be further adapted to be used while working with postgraduate students. In this case, elements of problembased learning [31] and open inquiry may be applied. The students can be asked to solve a simple development problem similar to those Research and Development (R\&D) departments in coatings companies encounter in their everyday work. The students' task could be to develop a lacquer which fulfills certain "customer" requirements, using the available raw materials. Like engineers working in coating R\&D laboratories, the students can work on a UV product formula trying to select suitable raw materials and find a right ratio between them to obtain the requested product parameters and performance. However, while using this approach, the students should be acquainted first with theoretical fundamentals of the process and the effects of the individual components on the properties of the lacquer.

\section{RESULTS AND DISCUSSION}

All students in each trial group prepared fully functional lacquers. Students could choose a painting technique (paintbrushes or applicators in range $30-120 \mu \mathrm{m}$ ), and three surfaces to be painted. To answer the question: Which lacquer is better?, all groups decided to compare multiple features of obtained coatings. The results depended strongly on painting technique (see exemplary fulfilled worksheets in the Supporting information). In general, students that used paintbrushes were applying thicker lacquer layers and that fact favored traditional lacquer. Thick layer of classical lacquers decrease their mass by about 10 times during drying, and effects with a homogeneous coating that adheres well to surfaces. The same thickness of a UV-layer layer doesn't decreases its mass and volume during curing, but the high thickness does adversely affect the coating elasticity, brittleness and hardness (see Fig. 7, topleft). On the other hand, groups that decided to control thicknesses of lacquer layers and obtained coatings in the range of 30 to $100 \mu \mathrm{m}$ picked the UV-lacquer as better one. Its surface was cured completely, adhered well and was very elastic. Thin layers of the classical lacquer were quite elastic and adhered well, but coatings were barely no- ticeable and didn't protect the surface properly. Therefore, it is advised to encourage students to use various painting techniques. Since it's obvious that film properties depend on film thickness (DFT - Dry Film Thickness) and due to such differences in solid content, students can be asked to calculate how much of paint (in grams) they need to apply for each paint to achieve the same DFT.

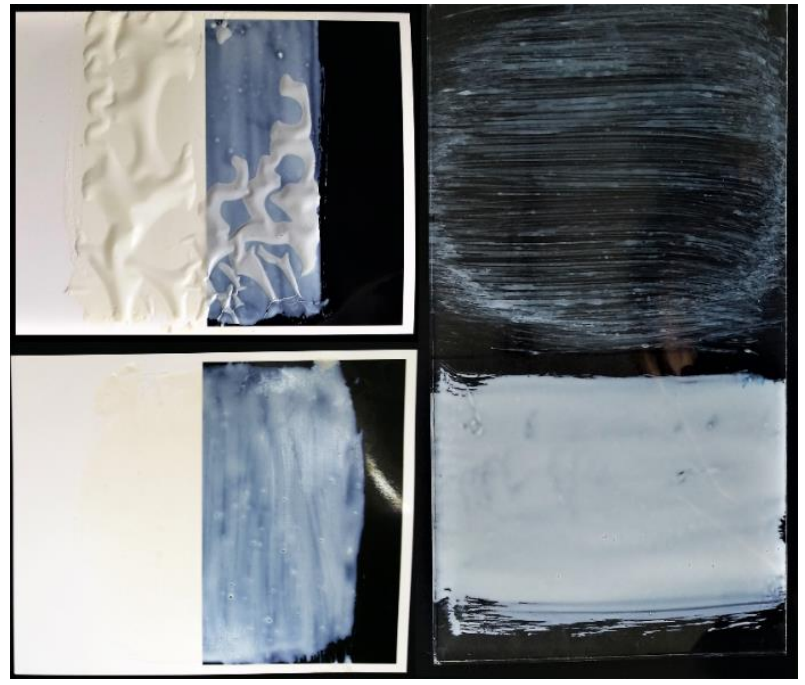

Fig. 7. Results of a painting of selected surfaces: on the left Leneta charts painted with the white UV-cured lacquer, top - paintbrush painting, bottom - Wire-Coater $32 \mu \mathrm{m}$; on the right glass surface painted with the traditional lacquer (top) and the UV-cured lacquer (bottom) both painted with Wire-Coater $32 \mu \mathrm{m}$

As a "green" lacquer the UV-cured one was chosen by all the student groups. In the reasoning, the students referred to Green Chemistry principles no. 3, 5, 6, 11 and 12. The main argument was measured mass loss during drying $(1-15 \%$ for the UV-lacquer and 70-90\% for the traditional one) thus no solvent emissions to the environment for the former. The students mentioned also the lower energy consumption during UV-curing.

Full pre- and post-test results are presented in the Supporting information. Analysis of the students' answers indicate that thanks to the exercise, the students improved their knowledge on lacquers and their properties. Interestingly, before the classes, a higher percentage of students described correctly the drying process of a UV-cured lacquer than that of a traditional one. Also, the answers were more extensive. After the classes, the students did not have problems describing both processes, but the average description of the curing process of UV-curable lacquers was still more detailed. Moreover, the pre-test answers indicate that the students have had many misconceptions con- 
cerning traditional and UV-cured lacquers, i.e., they believe that the UV-cured lacquers are expensive to purchase and use, harmful for the environment, flammable, unsuitable to be applied with a paintbrush and in multiple layers. After the classes, a smaller percentage of students gave these answers. Furthermore, the synthesis of lacquers showed that the process is similar and uncomplicated in both cases. The results of the pre-test concerning green chemistry may be considered surprisingly high. A comparison of results from the pre- and post-tests concerning green chemistry indicate a $17 \%$ increase in the number of correct answers, a statistically significant difference, what was concluded basing on the statistical tests carried out. Admittedly, the laboratory exercise itself does not concern the green chemistry issues, but the form of realization and the results obtained create an opportunity for students to acquire knowledge in this area.

\section{CONCLUSIONS}

The described laboratory exercise provides a unique way to introduce students to the green chemistry issues on the grounds of manufacturing and application of solvent-based and UV-cured lacquers. During the exercise, the students are acquainted with the processes of production, application, curing and testing of properties of lacquers. In spite of the significant simplification of the technological processes, the comparison of methods allows the students to formulate the expected conclusions on the impact of the analyzed technologies on the environment and relating them with the goals and some principles of green chemistry. Moreover, the inquiry-based method used develops students' skills in the area of the formulation of research questions, consistent arguments, conclusions, and teamwork. The scope of the exercise is in line with many of the US national Next Generation Science Standards (NGGS), including but not limited to standards in the categories of Matter and its Interactions, Earth and Human Activity, and Engineering Design, also addressed by incorporation of polymer science, green chemistry principles, and discussion of plastics in the environment [36]. For example, HS-ETS1-3 is "Evaluate a solution to a complex real-world problem based on prioritized criteria and trade-offs that account for a range of constraints, including cost, safety, reliability, and aesthetics as well as possible social, cultural, and environmental impacts [37]."

\section{SUPPORTING INFORMATION}

A complete student handout, instructor notes, exemplary results, pre- and post-tests with answer keys and results from testing groups are enclosed as associated content.

Acknowledgments. We would like to express our gratitude to BASF Company, which provided samples of prepolymers, reactive diluents, and photoinitiators enabling us to develop the described activity.

\section{REFERENCES}

[1] P. Anastas, J. Warner, Green Chemistry: Theory and Practice, Oxford University Press, New York, 1998.

[2] A. Matlack, Introduction to Green Chemistry, CRC Press, New York, 2001.

[3] R. K. Sharma, S. Gulati, S. Mehta, Preparation of gold nanoparticles using tea: A green chemistry experiment, J. Chem. Educ. 89, 1316-1318 (2012). DOI: https://doi.org/10.1021/ed2002175.

[4] O. US EPA, Pollution Prevention Act, 1990. https://www.epa.gov/p2/pollution-prevention-act-1990, accessed June 2018.

[5] 12 Principles of Green Chemistry - American Chemical Society.

https://www.acs.org/content/acs/en/greenchemistry/what-isgreen-chemistry/principles/12-principles-of-green-chemistry.html, accessed June 2018.

[6] P. T. Anastas, M. M. Kirchhoff, Origins, Current status, and future challenges of green chemistry, Acc. Chem. Res. 35, 686-694 (2002). DOI: https://doi.org/10.1021/ar010065m.

[7] B. Braun, R. Charney, A. Clarens, J. Farrugia, C. L. Kitchens, C. Lisowski, D. Naistat, A. O'Neil, Completing our education. Green chemistry in the curriculum, $J$. Chem. Educ. 83, 1126-1129 (2006).

[8] B. Bonifant, Competitive Implications of Environmental Regulation in the Paint and Coatings Industry, The Management Institute for Environment and Business (MEB), Washington DC, 1994.

[9] E. C. Holton, The story of paint and varnish. Part I, $J$. Chem. Educ. 5, 515 (1928). DOI: https://doi.org/10.1021/ed005p515.

[10] R. Calvert, Automobile lacquer, J. Chem. Educ. 2, 369 (1925). DOI: 10.1021/ed002p369.

[11] H. E. Hofmann, E. W. Reid, Formulation of Nitrocellulose Lacquers 1, Ind. Eng. Chem. 20, 687-694 (1928). DOI: https://doi.org/10.1021/ie50223a007.

[12] A. Orr, Lacquers as protective coatings, J. Chem. Educ. 3, 432 (1926). DOI: 10.1021/ed003p432.

[13] B. K. Brown, The use of plasticizers in lacquers, Ind. Eng. Chem. 17, 568-569 (1925). DOI: https://doi.org/10.1021/ie50186a005.

[14] M. H. Swann, M. L. Adams, G. G. Esposito, Analysis of lacquers containing nitrocellulose, alkyd resins, and 
phthalate-type plasticizers, Anal. Chem. 27, 1426-1429 (1955). DOI: https://doi.org/10.1021/ac60105a018.

[15] S. Benkendorf, F. A. Calamito, C. M. Zaccaria, Nitrocellulose lacquer composition containing gelatin and acrylic copolymers, United States Patent Ser. No. 06/246,836, 1983. http://www.google.com/patents/US4421881, accessed June 2018.

[16] R. S. Davidson, Exploring the Science, Technology and Applications of U. V. and E. B. Curing, SITA Technology Limited, 1999.

[17] B. K. Kim, K. H. Lee, H. D. Kim, Preparation and properties of UV-curable polyurethane acrylates, J. Appl. Polym. Sci. 60, 799-805 (1996).

DOI: https://doi.org/10.1002/(SICI)1097-4628(19960509) 60:6<799::AID-APP2>3.0.CO;2-E

[18] R. Liu, J. Luo, S. Ariyasivam, X. Liu, Z. Chen, High biocontent natural plant oil based UV-curable branched oligomers, Prog. Org. Coat. 105, 143-148 (2017). DOI: https://doi.org/10.1016/j.porgcoat.2016.11.009.

[19] L. Fertier, M. Ibert, C. Buffe, R. Saint-Loup, C. JolyDuhamel, J.-J. Robin, O. Giani, New biosourced UV curable coatings based on isosorbide, Prog. Org. Coat. 99, 393-399 (2016).

DOI: https://doi.org/10.1016/j.porgcoat.2016.07.001.

[20] UV/EB Brochure, Radtech Europe, 2012. https://www.radtech-europe.com/sites/default/files/rte uveb_brochure_2012.pdf, accessed June 2018.

[21] X. Xiao, C. Hao, Preparation of waterborne epoxy acrylate/silica sol hybrid materials and study of their UV curing behavior, Colloids Surf. Physicochem. Eng. Asp. 359, 82-87 (2010).

DOI: https://doi.org/10.1016/j.colsurfa.2010.01.067.

[22] G. Bogoeva-Gaceva, A. Buzarovska, Rapid method for evaluation of cure kinetics of thermoseting polymers, Maced. J. Chem. Chem. Eng. 32, 337-344 (2013). DOI: https://doi.org/10.20450/mjcce.2013.303.

[23] D. K. Chattopadhyay, S. S. Panda, K. V. S. N. Raju, Thermal and mechanical properties of epoxy acrylate/methacrylates UV cured coatings, Prog. Org. Coat. 54, 10-19 (2005).

DOI: https://doi.org/10.1016/j.porgcoat.2004.12.007.

[24] B. H. Thomas, The production of chemical cellulose from wood, J. Chem. Educ. 35, 493 (1958). DOI: https://doi.org/10.1021/ed035p493.

[25] J. J. Hinton, T. E. H. Gray, Method for manufacturing table-tennis balls, United States Patent Ser. No. 492,617, 1964. http://www.google.com/patents/US3617589, accessed June 2018.

[26] Toxicology studies of trimethylolpropane triacrylate (technical grade) (CAS No. 15625-89-5) in F344/N rats, B6C3F1 mice, and genetically modified (FVB Tg.AC hemizygous) mice (dermal studies), US National Toxicology Program, 2005.

https://www.ncbi.nlm.nih.gov/pubmed/18784763, accessed June 2018.

[27] Photoinitiators for UV Curing. Key Products Selection Guide 2003, Ciba, Basel, 2003.

http://www.academia.edu/32043252/Photoinitiators_for

UV_Curing_Key_Products_Selection_Guide_2003_Co ating_Effects, accessed June 2018.

[28] Leneta Wire-Cators ${ }^{\mathrm{TM}}$ on Leneta Co. http://opacity.leneta.com/viewitems/film-applicatorsand-accessories/leneta-wire-cators-, accessed June 2018.

[29] Paint \& Coating Test Charts \& Testing Equipment for the Paint and Coatings Industry.

http://www.leneta.com/index.html, accessed June 2018.

[30] J. Csernica, A. Brown, Effect of plasticizers on the properties of polystyrene films, J. Chem. Educ. 76, 1526 (1999). DOI: https://doi.org/10.1021/ed076p1526.

[31] C. J. Wenning, Levels of inquiry: Hierarchies of pedagogical practices and inquiry processes, J. Phys. Teach. Educ. Online. 2, 3-12 (2005).

[32] M. Windschitl, Inquiry projects in science teacher education: What can investigative experiences reveal about teacher thinking and eventual classroom practice?, Sci. Educ. 87, 112-143 (2003). DOI: https://doi.org/10.1002/sce.10044.

[33] Green chemistry high school test questions, ACS Green Chemistry Institute. https://www.acs.org/content/dam/acsorg/greenchemistry /education/resources/green-chemistry-test-questionslibrary.pdf, accessed June 2018.

[34] P. Bernard, I. Maciejowska, E. Odrowąż, K. Dudek, R. Geoghegan, Introduction of inquiry based science education into Polish Science Curriculum - General Findings of Teachers' Attitude, Chem.-Didact.-Ecol.-Metrol. 17, 49-59 (2012). DOI: https://doi.org/10.2478/cdem-2013-0004

[35] P. Bernard, I. Maciejowska, M. Krzeczkowska, E. Odrowąż, Influence of In-service Teacher Training on their Opinions about IBSE, Procedia - Soc. Behav. Sci. 177, 88-99 (2015). DOI: https://doi.org/10.1016/j.sbspro.2015.02.343.

[36] Next Generation Science Standards: For States, By States, National Research Council, The National Academies Press, Washington, DC, 2013. DOI: https://doi.org/10.17226/18290. https://www.nextgenscience.org, accessed June 2018.

[37] HS-ETS1-3 Engineering design, in: Next Generation Science Standards: For States, By States, National Research Council, The National Academies Press, Washington, DC, 2013. DOI: https://doi.org/10.17226/18290. https://www.nextgenscience.org/pe/hs-ets1-3-engineering-design, accessed June 2018. 